\title{
Maximizing the Innovative Behavior Through Worker's Engagement
}

\author{
Nisha Faradilla Sofiani ${ }^{1}$, Metha Djuwita Supriatna ${ }^{2}$ \\ Polytechnic of STIA LAN Bandung \\ \{metha.djuwita@poltek.stialanbandung.ac.id\}
}

\begin{abstract}
It is critical for a worker to continue to innovate in order to perform a role at work. Worker's innovation will accelerate the organization to the success gate. A worker must exhibit innovative behavior in order to continue to innovate. Organizations must be innovative in order to survive and adapt to changing conditions. Villages can benefit from innovation in adapting to change and responding to challenges brought about by these changes. Therefire, workers innovative behavior is one of the most important aspects of the organization. A person's innovative behavior can be influenced by a variety of factors. However, few studies have been conducted to date that examine the impact of work engagement on innovative behavior. This study aims to examine the impact of work engagement on the innovative behavior of workers. The population involved in this study were village workers from Majasari Village and Sliyeg Village, Indramayu City, and there were 42 people who participated in filling out the questionnaire. The questionnaire used is an adaptation of previous research which consists of two variables, namely work engagement and innovative behavior. The results showed that work engagement has a significant influence on the innovative behavior of workers. Thus, workers innovation can be maximized through increased work engagement.
\end{abstract}

Keywords: Innovative Behavior, Worker Engagement, Village Innovation

\section{Introduction}

The term "innovation" is being bandied about a lot these days. The development and implementation of new ideas by people who engage in transactions with others over time within an institutional order is defined as innovation [1]. Others defined innovation as an effort to utilize thoughts, abilities, imagination, sharing stimulants in producing a new product [2]. As a result, it is possible to conclude that innovation is associated with the result of thinking that aims to produce something new.

In organizations, innovation is critical. Organizations that innovate can contribute to market share faster while also growing it [3]. Every organization is now confronted with a situation in which change is increasingly becoming a requirement in order to maintain the organization's continuity. Many factors, such as technological advancements, government policies, economic globalization, and so on, are driving these changes. Organizations must be able to continuously renew themselves in order to survive and adapt to all changes. As a result, in every organization, creativity and innovation play a significant role. When an organization has an innovative culture, it can survive and grow in today's world. 
The importance of innovation in ensuring the viability of the village cannot be overstated. Innovation can assist villages in adapting to change and responding to challenges brought about by these changes. Consequently, the village can provide services to the community in a more effective and efficient manner. Through various development activities and village community empowerment, innovation can also help to reduce rural poverty by utilizing village funds in a more quality, effective, and efficient manner.

There are numerous factors that can have an impact on innovation. These factors can be grouped into three major groups, namely environmental factors, individual factors and organizational factors [4]. Ideas are the foundation of all innovative improvement. Individual employees are responsible for 'developing, carrying, reacting to, and modifying ideas' [1]. Innovative work behavior displayed by every individual in the organization can boost the organization's ability and innovative output. This illustrates that individual factors play a significant role in increasing the level of innovation in a company [2]. This demonstrates the importance of village workers in increasing innovation. Village workers who exhibit high levels of innovation can contribute to the organization's long-term viability.

Scholars have begun to pay greater attention to the attitudinal factors that help induce innovative behavior, assuming that innovative behaviors stem not only from an individual's natural traits but also from an individual's job attitudes. Worker's engagement is one of these factors. The intensity and direction of cognitive, emotional, and behavioral energy operationalizes workers engagement [5]. Scholars also recognize that the various individual and contextual factors that influence workers engagement have received little attention in the context of innovative behavior [6]. Despite this, there hasn't been much research on the impact of workers engagement on innovative behavior. As a result, this study aims to examine the impact of work engagement on the innovative behavior of village workers.

\section{Theoretical Backgrounds}

\subsection{Workers Engagement}

The concept of workplace engagement is defined as a positive, fulfilling, work-related state of mind characterized by vigor, dedication, and absorption [7]. Individuals who are engaged bring all aspects of themselves to their work role, including cognitive, emotional, and physical aspects. Thus, being fully engaged entails individuals displaying their entire selves within the roles they are playing. Individuals who are disengaged, on the other hand, decouple themselves from their work roles.

Many studies have attempted to identify the factors that lead to workers engagement and have developed models to draw implications for managers. Their analysis seeks to identify the factors that will increase workers engagement. The majority of the drivers discovered to lead to workers engagement are non-financial in nature. As a result, any organization with committed leadership can achieve the desired level of engagement at a lower cost [8].

Workers engagement has been found to have a positive relationship with organizational performance outcomes such as workers retention, productivity, profitability, customer loyalty, and safety. According to studies, the more engaged workers are, the more likely their employer is to outperform the industry average in revenue growth [9][8], [10]. Companies with disengaged workers, on the other hand, waste effort and bleed talent, earn less commitment from workerss, face increased absenteeism, and have less customer orientation, productivity, and operating margins and net profit margins [8]. 


\subsection{Innovative Behavior}

The terms creativity and innovation are inextricably linked, but there is a significant difference between the two. Innovation is an effort by individuals to use their thinking, imagination, and sharing stimulants to create new products. In today's environment, organizations must be able to continuously innovate and improve their products, services, and processes [2]. While innovative behavior is a process of finding creative ways to solve a problem. Individuals engage in innovative behavior when they introduce new ideas, processes, products, or procedures that can be useful at work, in groups, or in organizations. Innovative work behavior typically includes the exploration of opportunities, but it can also include behavior that leads to the implementation of change, the application of new knowledge, or the improvement of processes to improve individual, group, or organizational performance. [2], [11].

There are three dimensions to measuring innovative behavior in the workplace: idea generation, idea promotion, and idea realization. These three dimensions serve as the foundation for the development of innovative work behavior in workers [11]. Innovative behavior often occurs over the course of planned change with specific goals in mind, and involves actions such as seeking out new ideas, championing new initiatives, and securing planning/funding for the ideas' implementation [12].

\section{Methods}

This research uses quantitative methods as well as verification techniques. The verification method is used to investigate the effect of workers engagement on innovative behavior. A questionnaire was used to collect data. The questionnaire that was distributed included the two research variables that were used: worker engagement and innovative behavior. Purposive sampling was used to determine where the study would take place. The participants in this study were 42 village workers from two villages in Indramayu Regency: Majasari Village and Sliyeg Village. After that, the sample is determined using the saturated sample technique.

The primary data source was a questionnaire related to the two research variables, namely workers engagement and innovative behavior. Both instruments were modified from previous studies. The variable of innovative behavior was adapted from research conducted by Yu et.al, which consisted of nine (9) statement items [13]. Whilst the employee engagement variable uses the UWES (Ultretch Work Engagement Scale) which was developed by Schaufeli and is used in several countries. This instrument consists of three (3) dimensions, namely vigor, absorption, and dedication, with a total of seventeen (17) statement items. All indicators in this study used a Likert scale with five ratings, namely strongly disagree, disagree, quite agree, agree, and strongly agree. The data were then analyzed using simple regression analysis to examine the impact of workers engagement on innovative behavior.

\section{Results and Discussion}

A questionnaire related to the two research variables, namely worker engagement and innovative behavior, served as the primary data source. Both instruments have passed the stage of validity and reliability testing. The results of the validity and reliability tests show that all of the statement items used in the study, both the variables of innovative behavior and worker engagement, are valid and reliable. This is because the validity test reveals that all statement 
items have a $\mathrm{r}$ count $>\mathrm{r}$ critical value. In terms of reliability testing, both variables have Cronbach's alpha values greater than 0.6.

The table below shows the average score of the statement items. In the variable of innovative behavior, all statement items have an average score in the high category. Village workers in Majasari Village and Sliyeg Village believed that solving difficult problems was usually done by creating original solutions, or solutions that had never existed before; the innovative ideas expressed also received approval from the office, in this case the Majasari Village and Sliyeg Village offices; the innovative ideas expressed by village workers made their superiors enthusiastic; village workers can also transform innovative ideas into useful applications; previously generated innovative ideas are evaluated and then introduced in a systematic manner.

With the statement item "our office supports innovative ideas," the highest average value for this variable is 4.17. This means that the offices in Sliyeg Village and Majasari Village are open to new ideas generated by their workers. Several village innovations have been implemented so far, not only in the village that initiated the innovation, but in other villages in Indramayu Regency. Majasari Village's innovations include the conversion of agricultural waste rice husks into animal feed and the development of the concept of communal husbandry, which is a BUMDes activity, the conversion of livestock waste into biogas, village regulations for the protection of Indonesian migrant workers (TKI) from Majasari Village, and educational houses TKI to provide education and skills related to foreign languages and cultures where prospective migrant workers will work, savings and loan cooperatives, village libraries equipped with internet connections, children's reading areas in the Majasari Village Hall building, village community radio as a means of sharing information and entertainment for residents, as well as access free wireless internet for residents whose family members work as migrant workers so that they can communicate. Protecting TKI is one of Majasari village's most popular innovations on a national scale.

This village founded the Community Based Organization (CBO) Zulfikar, which provides three TKI-related services, namely access to information, advocacy, and finance, in order to ensure the welfare of Majasari Village residents who work as TKI. Although the variable of innovative behavior is in the high category, it can be raised to very high by: 1) providing training and self-development, 2) providing examples from superiors, and 3) creating an environment that strongly encourages innovation [14].

Table 1. Average Statement Item Score

\begin{tabular}{cccccc}
\hline Item & $\begin{array}{c}\text { Innovative Behavior } \\
\text { Mean }\end{array}$ & Category & Item & $\begin{array}{c}\text { Workers Engagement } \\
\text { Mean }\end{array}$ & Category \\
\hline 1 & 3.95 & High & 1 & 3.90 & High \\
2 & 3.64 & High & 2 & 4.10 & High \\
3 & 3.57 & High & 3 & 3.69 & High \\
4 & 4.17 & High & 4 & 3.88 & High \\
5 & 4.02 & High & 5 & 4.05 & High \\
6 & 3.95 & High & 6 & 3.02 & Medium \\
7 & 3.98 & High & 7 & 4.07 & High \\
8 & 3.93 & High & 8 & 4.12 & High \\
9 & 3.98 & High & 9 & 3.90 & High \\
& & & 10 & 4.26 & High \\
& & & 11 & 3.19 & Medium \\
& & & 12 & 3.60 & High
\end{tabular}




\begin{tabular}{ccccc}
\hline \multirow{2}{*}{$\begin{array}{c}\text { Innovative Behavior } \\
\text { Item }\end{array}$} & Mean & Category & Item & Workers Engagement \\
& & 13 & 3.40 & Category \\
\hline & 14 & 3.45 & High \\
& 15 & 3.45 & High \\
& 16 & 3.21 & High \\
& 17 & 3.31 & Medium \\
& & Medium \\
\hline
\end{tabular}

The statement item scores for the workers engagement variable have an average value in the high and medium categories. The statement item "I am proud of the work I do" received the highest score on this variable that is 4.26. This means that village employees are proud to work in the village office, especially for Majasari Village, which was named the Best Village in 2016.

The statement item "When I'm at work, I forget everything else around me" has the lowest value for the workers engagement variable, 3.02, and it falls into the medium category. This is due to the fact that some workers, particularly in Sliyeg Village, have second jobs. In this regard, the Sliyeg Village Head does not prohibit his employees from working on the side as long as the village work can be handled and completed.

Table 2. Average Total Variable Score

\begin{tabular}{ccc}
\hline Variable & Mean & Category \\
\hline Innovative Behavior & 3.91 & High \\
Workers Engagement & 3.68 & High \\
\hline
\end{tabular}

The average total score for the variable of innovative behavior is 3.91 , and the average total score for the variable of worker engagement is 3.68 , both of which are in the high category. This means that the Sliyeg and Majasari village workers are open to change, capable of applying new knowledge or improving processes in order to improve individual, group, or organizational performance. There are several things that can be done to increase workers' innovative behavior, such as providing challenging jobs, giving workers work autonomy and sufficient control, and encouraging workers to always maintain good relations with external parties [15].

Furthermore, workers in Sliyeg and Majasari villages feel emotionally and cognitively bonded when they know what is expected of them, have what they need to get the job done, have the opportunity to feel the impact and fulfillment of their work, feel that they are a part of something significant with trusted colleagues, and have opportunities to improve and develop. Workers who are highly engaged at work are more likely to give their best effort because they enjoy what they do [16]. Building good working relationships between workers and workers with superiors, making a clear division of responsibilities so that workers know what work they really have to do, and creating a positive work culture are all ways to encourage a climate of high work engagement among workers [17].

The collected data was then tested for the effect of work engagement on innovative behavior using a simple linear regression statistical test. With a unidirectional relationship between work engagement and innovative behavior, the constant value is 14,465 , which means that if work engagement is zero, the growth of innovative behavior is worth 14,665 . The regression coefficient is 0.331 , indicating that the relationship between the two variables is unidirectional. As a result, an increase in work engagement leads to an increase in innovative behavior, whereas a decrease in work engagement leads to a decrease in innovative behavior among workers. 
Table 3. Calculation Result of Simple Linear Regression Analysis

\begin{tabular}{lccccc}
\hline & \multicolumn{3}{c}{ Unstandardized Coefficients } & t & Sig. \\
\cline { 2 - 3 } (Constant) & $\mathrm{B}$ & Std. Error & Beta & & \\
Workers & 14.465 & 4.005 & & 3.612 & .001 \\
Engagement & .331 & .063 & .638 & 5.236 & .000 \\
(X1) & \multicolumn{7}{c}{} & & & \\
\hline
\end{tabular}

The correlation coefficient between the two variables is 0.638 , indicating that the correlation between the two variables is strong. While the R Square value obtained is 0.407 , this means that work engagement can explain 40.7 of the variances in innovative behavior, and the rest can be explained by variables other than the research variables. A t test is used to determine whether work engagement has an effect on innovative behavior. According to the test results, the value of $t$ count is 5.236, while the value of $t$ table is 1.68385 , where the value of $t$-count $>$ t-table with sig 0.05 is found.

This means that with a $95 \%$ confidence level, it is possible to conclude that work engagement has an impact on innovative behavior or that innovative behavior can be enhanced through increased work engagement. The findings of this study are consistent with previous research, which found that work engagement has an impact on innovative behavior [18]. Job engagement is a positive feeling experienced by a worker, and this positive feeling can encourage the acceptance of information and flexible thinking, allowing the worker to take the initiative, particularly in the workplace.

\section{Conclusion}

Innovative behavior can motivate workers to come up with new ideas, new innovations, and new plans that can be used to develop or even create solutions to existing problems. Innovative work behavior is typically defined as behavior that leads to the implementation of change, the application of new knowledge, or the improvement of processes in order to improve individual, group, or organizational performance. Every worker, including village workers, needs to be innovative.

This study discovered that work engagement can influence innovative behavior. In other words, increasing work engagement can boost innovative behavior. Job engagement is a positive feeling experienced by a worker, and this positive feeling can encourage the acceptance of information and flexible thinking, allowing the worker to take the initiative, particularly in the workplace. This study also found that work engagement and innovative behavior were in the high category. This means that the Sliyeg and Majasari village workers are open to change, capable of applying new knowledge or improving processes in order to improve individual, group, or organizational performance.

There are several things that can be done to improve workers' innovative behavior, such as providing challenging work, giving workers enough autonomy and control, and encouraging workers to always maintain good relationships with external parties. Furthermore, workers in Sliyeg and Majasari villages feel emotionally and cognitively bonded when they know what is expected of them, have what they need to get the job done, have the opportunity to feel the impact and fulfillment of their work, feel like they are a part of something meaningful with trusted colleagues, and have opportunities to improve and develop. Workers who are highly engaged at work are more likely to give their best effort because they enjoy what they do. 
Building good working relationships between staff members with superiors, making a clear division of responsibilities so that workers know what work they really have to do, and creating a positive work culture are all ways to encourage a climate of high work engagement among workers.

\section{References}

[1] A. H. Van de Ven, "Central Problem in The Management of Innovation," Manage. Sci., vol. 32, no. 5, pp. 590-607, 1986.

[2] J. P. . De Jong and D. N. Den Hartog, "Innovative Work Behaviour: Measurement and Validation," no. November, 2008.

[3] T. Handerson, "Why Innovation Is Crucial To Your Organization's Long-Term Success," 2017. .

[4] J. C. N. Valencia, R. S. Valle, and D. J. Jimenez, "Organizational Culture as Determinant of Product Innovation," Eur. J. Innov. Manag., vol. 13, no. 4, pp. 466-480, 2010, doi: 10.1108/14601061011086294.

[5] B. Shuck, J. L. Adelson, and T. G. R. Jr, "The Employee Engagement Scale: Initial Evidence For Construct Validity and Implications for Theory and Practice," vol. 56, no. 6, pp. 953-977, 2017, doi: $10.1002 / \mathrm{hrm}$.

[6] K. Kwon and T. Kim, "Human Resource Management Review An integrative literature review of employee engagement and innovative behavior : Revisiting the JD-R model," Hum. Resour. Manag. Rev., no. August, p. 100704, 2019, doi: 10.1016/j.hrmr.2019.100704.

[7] W. B. Schaufeli and A. B. Bakker, Defining and measuring work engagement: Bringing clarity to the concept. 2010.

[8] M. S. Yousif Ali and A. H. Ali Hasaballah, "Assessing the effect of organizational cultural values and employees engagement on performance excellence," Int. J. Manag., vol. 11, no. 4, pp. 108-126, 2020, doi: 10.34218/IJM.11.4.2020.013.

[9] L. A. Hambley, T. A. O’Neill, and T. J. B. Kline, "Virtual team leadership: The effects of leadership style and communication medium on team interaction styles and outcomes," Organ. Behav. Hum. Decis. Process., vol. 103, no. 1, pp. 1-20, 2007, doi: 10.1016/j.obhdp.2006.09.004.

[10] C. Coffman, "Is Your Company Bleeding Talent? How to become a true "employer of choice," Gall. Manag. J., 2020

[11] O. Janssen, "Job Demands, Perceptions of Effort-Reward Fairness and Innovative Work Behaviour," pp. 287-302, 2000 .

[12] P. Cardellino and E. Finch, "Evidence of systematic approaches to innovation in facilities management," J. Facil. Manag., vol. 4, no. 3, pp. 150-166, 2006, doi: 10.1108/14725960610673742.

[13] C. Yu, T. F. Yu, and C. C. Yu, "Knowledge sharing, organizational climate, and innovative behavior: A cross-level analysis of effects," Soc. Behav. Pers., vol. 41, no. 1, pp. 143-156, 2013, doi: 10.2224/sbp.2013.41.1.143.

[14] M. D. Supriatna, “The Role of Creative Self-Efficacy to Increase Researcher's Innovative Behavior," Int. J. Acad. Res. Bus. Soc. Sci., vol. 9, no. 9, pp. 744-758, 2019, doi: 10.6007/IJARBSS/v9-i9/6376.

[15] J. P. . De Jong and R. Kemp, "Determinants of Co-Workers Innovative Behaviour: An Investigation into Knowledge Intensive Services," vol. 7, no. 2, pp. 189-212, 2003.

[16] A. D. S. Deviyanti and A.D., "Pengaruh Sumber Daya Pekerjaan (Job Resources) dengan Keterikatan Kerja (Work Engagement) sebagai Mediator terhadap Perilaku Proaktif,” J. Ilmu Manaj. Magistra, vol. 1, no. 1, p. 18, 2015.

[17] W. H. Macey and B. Schneider, "The Meaning of Employee Engagement," Ind. Organ. Psychol., vol. 1, no. 01, pp. 3-30, 2008, doi: 10.1111/j.1754-9434.2007.0002.x.

[18] R. Anwar and S. H. M. Niode, "The Effects of Learning Organization towards Employes' Innovative Behavior Mediated by Work Engagement (A Study in Indonesia)," in Advance in Intelligent Systems Research, 2017, vol. 131, pp. 159-164, doi: 10.2991/icoi-17.2017.15. 